\title{
The Case of the Baltic Region: The History of the Faculty of Trade and Commerce
}

\author{
Dzintra Atstaja, Ivars Brivers \\ BA School of Business and Finance, Riga, Latvia \\ Ieva Bruksle \\ School of Business Administration "Turiba”, Riga, Latvia \\ Alida Zigmunde \\ Riga Technical University, Riga, Latvia
}

\begin{abstract}
In the anticipation of the 150th anniversary of the Riga Technical University (Latvia), some questions have become the objects of historical research. This article is devoted to the beginnings of the Faculty of Trade and Commerce in Latvia. The article reviews the historical situation and documents characterising the establishment of the faculty of the new educational institution; attention has been mostly paid to the history up to 1896 when the school underwent reorganisation.
\end{abstract}

Keywords: education, Riga, study process

\section{Introduction}

This article deals with the Livonian town of Riga in the middle of the 19th century, with the great economic changes in the economy, with economic growth, with the transition from manufactory to industry, with the shift from hand labour to machinery. With the development of the city and the railway, Riga becomes the junction point between the east and the west, between Europe and Russia.

Around the 19th century the Baltic region, especially Riga, started to take a more and more prominent position within what was then the Russian Empire. In Eastern Europe, Riga had once again become a substantial traffic and mediation centre with western Europe and other parts of the world. With the development of the port, Riga became a new influential factor in world trade. Therefore, more serious attention was paid to the land transportation system as well, and large funds were invested in the construction of land traffic routes, especially the railway, to this important centre-Riga. All of this contributed to the development of the local industry.

At the beginning of the 19th century, the population of Riga gradually increased. It fell substantially during the war of 1812 and the next decade, but increased quickly during the second half of the $1820 \mathrm{~s}$, and especially since the $1860 \mathrm{~s}$, mostly because after the liberation of the peasants from their patrons, a huge

Dzintra Atstaja, Associate Professor, Dr. oec., Department of entrepreneurship and IT, BA School of Business and Finance. Ivars Brivers, Professor, Department of entrepreneurship and IT, BA School of Business and Finance.

Ieva Bruksle, Mg. oec., Ph.D. candidate, Lecturer, Department of Commerce, School of Business Administration "Turiba".

Alida Zigmunde, Dr. paed., Senior researcher, Institute of Humanities, Riga Technical University.

Correspondence concerning this article should be addressed to Dzintra Atstaja, Valdemara 161, Riga, LV1013, Latvia. E-mail: dzintra.atstaja@gmail.com. 
migration of the population from the countryside began to the industrial centre Riga. Since 1867, the city of Riga has started to hold population census, therefore the demographic data become more precise. In the second half of the 19th century, remarkable changes took place in the ethnic composition of the inhabitants of Riga. The proportion of the Latvian-speaking inhabitants increased from $23.6 \%$ in 1867 to $40.4 \%$ in 1913 . The percentage of Baltic Germans fell from $42.9 \%$ in 1867 to $15.9 \%$ in 1913 . The proportion of Russians in Riga decreased from $25.1 \%$ in 1867 to $21.8 \%$ in 1913. Poles had not been counted in 1867, in 1913 they were counted 7.2\% (Hirschhausen, 2006).

In Riga, as well as in other regions of Latvia and Estonia, there was a large demand for qualified engineers, but in the Baltic provinces there was no appropriate educational institution. Within the whole of extensive Russia, such technical educational institutions were located only in Petersburg, Moscow, and Helsinki (Finland); but these were just in their first stages of development. The lack of knowledge of foreign languages hindered the local people to attend these institutions. On the other hand, studies abroad are very costly. As a result, in the Baltic provinces, the technically qualified workforce was composed of foreigners, basically Germans who had studied in Germany and had come to Livonia (Bērziņš, 1937).

\section{The Historical and Geopolitical Context}

The foundation of the Riga Polytechnic School (Rigasche Polytechnische Schule) in 1862 was a significant event not only in the history of Latvia, but in the whole Baltic region of the Russian Empire.

The Baltic Germans had a special status in the Baltic provinces. When the Poles conquered the Baltics from the Order of the German Knights, the German Barons for their submission under the Polish rule, had been granted on November 28th, 1561, the Privileges of King Sigismund (of Poland) (Privilegium Sigismundi Augusti: German self-administration, German language, German belief (Lutheran) and some privileges concerning properties). These privileges had been renewed by the Swedes when they defeated the Poles in 1629 and they had been renewed by Peter the Great, Tsar of Russia in 1721 when he defeated the Swedes. After the Great Nordic War the Estonian part and the Livonia part of the Baltic became part of the Russian Empire (Peace treaty of Nystad 1721). Only in 1795 after the third partition of Poland Courland and Lithuania with Latgale became part of the Russian Empire. Estonia and Livonia as well as Courland were of Lutheran-protestant belief while Lithuania had its common history with Poland and had stayed Catholic.

Almost all persons with higher education in Livonia were Germans. The Baltic Germans had a very big influence also in other regions of the Russian Empire.

Sneps-Sneppe (2011) in his published book Germans in Russia mentioned the fact that at the end of the 19th century:

- Fifteen percent of the Ministers;

- Twenty five percent of the Members of the State Council;

- Forty percent of the Senators;

- Fifty percent of the Army Generals;

- Sixty three percent of the Governors

were ethnic Germans, mainly German Barons from Livonia.

After the Baltic territory was included into the Russian Empire, the boundaries of the Russian provinces did not correspond to the ethnicity of their inhabitants.

The governorate of Livonia included not only the territory of the Latvians living there, but in its northern 
part it included a large part which is inhabited by Estonians with cities like Dorpat-Tartu-Juryev (Юрьев), where in 1632 the first University in Livonia - the Academia Gustaviana (founded by Gustav Adolf King of Sweden on a battlefield in the 30-years' war) was established, which was closed in 1710, but was re-established in 1802 .

The governorate of Livonia with its administrative and economic center in Riga and its scientific and educational center in Dorpat, was clearly the most developed Governorate in the Baltics and one of the most developed in the whole Russian Empire. For comparison-Moscow University established in 1755, but Saint-Petersburg University in 1819.

The University in Vilnius was opened even earlier then the University in Dorpat—in 1579. Still at this time it was relevant to the other cultural space - Catholic-Polish.

The second half of the 19th century was a time of a very rapid development in the whole Russian Empire, and especially in the Baltics. Riga became the third largest industrial centre of the Russian Empire with the most modern industries. So there appeared a necessity for a scientific centre in Riga, based mainly on technical sciences. This was the foundation of the idea for establishing a polytechnic school in Riga.

Though until now Riga had never shown any efforts to have a university there existed traditions of scientific research mainly in technical sciences, and some famous scientists were closely connected with Riga. One of the most popular is the German-French physicist Georg Friedrich Parrot, who was born in France in 1767. Parrot studied at the University in Stuttgart, started his scientific career in Paris, but in 1795 he moved to Riga, and lived here until 1801, when he became the first rector of the re-established University of Dorpat/Tartu (Stradiņš, 1982).

Among other famous scientists of that time in Riga, we may mention the chemist David Hieronymus Grindel, who had ethnical Latvian roots. Grindel is memorialized in the name of the present Latvian pharmaceutical company "Grindex". Another famous scientist Wilhelm Christian Friebe had studied theology at the University in Göttingen, but has gained popularity as a scientist with a wide range in natural sciences. Riga had traditions in a pharmacy, where we can mention such names as Ernst Ludolf Seezen, Richard Georg Kersting, Karl Heinrich Frederking, etc. (Stradinš̌, 2009). This scientific environment was considered as a good basis for opening an institution of higher technic education in Riga.

The best German and Swiss Polytechnic schools were taken as an example for this project-the Polytechnic School of Karlsruhe and the Polytechnic School in Zürich, now ETH Zürich. A large number of professors and lecturers were invited from Germany and Switzerland, because the language of tuition was German. The first director of the Riga Polytechnic School was the physicist Ernst Nauck (1819-1875), a former principal of the Krefeld School of Crafts in Germany. Among the first professors who should be mentioned for instance professor Ernst Louis Étienne Laspeyres (1834-1913), he moved from Basel to Riga to organize the Department of Trade in the Riga Polytechnic School (Kieseritzky, 1887). Some of the professors and lecturers of the Riga Polytechnic School had graduated from the University of Dorpat - the physicists and mathematicians Piers Bohl, Theodor Grönberg, Gustav Kieseritzky, Karl Reinhold Kupffer, Alfred Meder, Hermann Pflaum, the specialists of agricultural science Jegor von Sivers, Karl Hehn, Guido Schneider, George Thoms, Woldemar von Knieriem (the grandfather of Swedish Prime Minister Olof Palme), etc. (Album, 1912). From 1906 till 1916 von Knieriem was the director of the Riga Polytechnic Institute. Thus the Riga Polytechnic School was considered as the best Polytechnic School in the whole Russian Empire.

Among the most important scientists who have worked at the Polytechnic School in Riga are the famous 
chemist Wilhelm Ostwald (1853-1932), who worked as a professor of chemistry (1881-1887) and later in 1909 became the only Nobel Prize Laureate from the Baltics and the alumnus and later professor of his Alma Mater Paul Walden (1863-1957) who is the founder of the dynamic stereochemistry and electrochemistry of non-aqueous dilutions. Walden was nominated 10 times for the Nobel Prize and he would have received it in 1914 if the First World War had not started (RTU, 2012).

At the beginning, the Riga Polytechnic School began to work in the building on the corner of the present K. Barona and Elizabetes streets. In 1869 a new building was inaugurated on the present Rainis Boulevard, which in 1919 became the main building of the University of Latvia when the Polytechnic Institute was shut down after Latvia got its independence (Neunter, 1870). The building process continued until 1910, and since this time the building has taken its present look.

The Polytechnic School in Riga was an institution, which got its students from all over the Russian Empire. There were not only Latvians, but also Germans, Russians, Poles, Lithuanians, Jews and a few people from other regions of the Empire. The language of education was German, so we find professors and other staff from all German speaking countries, but among them also Jews, Russian, Swiss citizens. There were also Latvians or people from mixed families like the chemist Paul Walden who became the Rector of the Polytechnic Institute (1902-1905, 1917-1918) and the dean of the Department of Trade - Karl August Lieventhal who was the son of the Latvian poet Ansis Līventāls and his mother was German. The economist Lieventhal had graduated from the University of Dorpat where he studied economy and one of his professors was Laspeyres.

The history of the Riga Polytechnic School surely is a subject of interest for study not only from the point of view of Latvian history, but Russian and German history as well.

\section{The Establishment of the Educational Institution}

When in 1857 the walls of the fortified town of Riga were torn down, the city gained new economic breath, large economic changes take place- economic growth, the transition from manufactory to industry, the shift from hand labour to machinery.

The development of the city continues, the railway gets built and Riga becomes the junction point between the east and the west. All this promoted by the development of trade and the necessity for traders to acquire comprehensive knowledge that would allow them to meet the demand, avoid obstacles, and enjoy the fruit of their labour.

The need for technical experts motivated the stakeholders of the Riga Stock Exchange to seek a solution in Riga.

On January 1st, 1858, to the Riga Stock Exchange Committee was submitted a "Project for the Technology and Trade School in Riga". The same year on January 28th the committee decided to raise the issue at the traders' general meeting, yet preliminary to be discussed by a special commission. The first corresponding commission, which consisted only of stock-exchange traders, came to the conclusion that the establishment of such school should take place with the involvement of the City Council and the Baltic landlords as well.

On October 20th, 1858, another joint commission was established representing project applicants and the Stock Exchange Committee, which was more successful in promoting the case. The same year, on November 30th, the new commission turned to the Stock Exchange Committee with a request to allocate funds for the invitation of an appropriate specialist. The Committee supported the request, and as a specialist was invited Dr. 
Franke, the vice-director of the Polytechnic School of Hanover/Germany.

In February, 1859, Franke arrived in Riga and after finding that the project was too limited developed a new one for the "Central trade and craft school" which was submitted to the above-mentioned commission. On March 3rd of the same year, he held a public lecture on the subject, which created a lively discussion and an agreement among the stakeholders (Kieseritzky, 1887).

On March 9th, 1859, the joint commission accepted Franke's proposals in general; while a day later they were accepted also by the first applicants, who delegated the promotion of the project to the Stock Exchange Committee itself.

At the general meeting of March 22nd, 1859, the traders, who were paying taxes to the Stock Exchange Committee for general trade-related purposes, received the project proposal with enthusiasm and decided to allocate an annual subvention of 5,000 roubles to the prospective school, asking the Stock Exchange Committee to involve the wider community of Riga and the Baltic provinces. For this purpose the Committee issued a brochure "The designed Central trade and craft school in Riga".

On May 19th, 1859, the Stock Exchange Committee called on the Riga City Council and the members of both guilds with a request to grant a royalty-free parcel of land as well as corresponding subventions (Bērzinšs, 1937).

Apart from the aforementioned Riga traders, the number of financial supporters of the designed school increased by the guilds of the city of Dorpat, who announced their single payment already in 1859 . On November 10th of the same year, the Riga city council reported to the Committee that they have decided to allocate for the designed school:

- A suitable parcel of land;

- One hundred thousand silver roubles for construction work (Anlagekosten);

- Three thousand silver roubles if needed as an annual subvention (Bērziņš, 1937).

On November 22nd, 1859, the Stock Exchange Committee called on the Prince A. Suvorov, the Governor-General of the Baltic region who was very favourable with regard to the German population, to undertake the promotion of the issue at the highest governmental level. The request was accompanied with wide substantiation of the need to establish the designed school, as well as its statutes and budget drafts. There was as well stated that the new educational institution should be subordinated to the Ministry of Finance and the Governor-General of the Baltic region himself.

In February, 1860, the Ministry of Finance announced that they upheld the decision of the Riga city council to support of the designed school. Meanwhile, during the confirmation process of the school's statutes new obstacles arose, due to which the Riga Stock Exchange Committee was forced to delegate its representative to St.-Petersburg. After corresponding with the department of industry, the representative introduced amendments within the statutes among which the designed school gained a new name-Polytechnic School of Riga. Regardless all the amendments the Minister for Finance rose new objections against the statutes.

Thus began a lengthy correspondence between the Minister for Finance and the Stock Exchange Committee mediated by the General Governor until the autumn of 1860. As professor Kieseritzky (1887) has written in his book "Die Entstehung des baltischen Polytechnikums und die ersten fünfundzwanzig Jahre seines Bestehens (The foundation of the Polytechnic School of the Baltics and the first 25 years of its existence)"-For some time, it really seemed that all effort had been in vain, as the supporting entities insisted on providing 
funding only to a complete polytechnic institute.

In November, 1860, the parliamentary meeting of the landowners of Livonia (Livländischer Landtag) decided to allocate to the polytechnic school 2,000 roubles annually for 12 years. Finally the prince Suvorov compelled the Minister for Finance Knyazevich to come up at the Russian State Council's spring session (1861) with a proposal that would comply with the expectations of the Stock Exchange Committee. As a result, on May 13th of the same year the Russian State Council provided the expected resolution concerning the Riga Polytechnic School, which was confirmed together with its statutes by the Emperor. According to these statutes the Polytechnic School in Riga was subordinated to the Ministry of Finance and the Governor-General of the Baltic region was appointed as its curator. The school was to be funded by the donations of the different entities of the Baltic provinces, as well as by student fees.

Thus, meeting the challenges of the new time on October 14th, 1862, the Polytechnic School in Riga was opened with 15 students. The school started with three departments and the Department of Trade among them (Schiemann, 1918).

But when they prepared to start the Polytechnic School they found out that the future students would not have the necessary basic knowledge in mathematics, physics, and chemistry which is necessary before starting to study. As a better solution was taken the proposal by Dr. Phil. Karl von Bornhaupt (1802-1889) to transform the higher classes of his private gymnasium into preparatory classes for a polytechnic school. Bornhaupt compiled a special project for the establishment of a secondary school according to foreign models (Frooben, 1884).

So in 1862 only the preparatory class was started, which later was renamed "Pre-school of the Polytechnic School in Riga". Specialised departments started operation only in the next autumn (Bērziņš, 1937).

It should be noted that on May 16th, 1861, Emperor Alexander II approved the proposal of the general meeting of the State Council "On the establishment of the Polytechnic School in Riga" and signed the statute of the school. The Riga Polytechnic School started functioning a year later, on October 14th (2nd, old style) 1862. An organisational plan was published according to which the school would consist of eight departments, the first of which would be called "Commerce School". The inclusion of the Department of Commerce into the polytechnic school largely depended on the perception held by the government and especially by entrepreneurs and the entrepreneurship. Eduard Hollander, president of the Administrative Council of the Polytechnic School notes at the inauguration, that with the establishment of not a separate academy of commerce, but by linking it with a technical school (most local factories belong to traders) further all graduates of the polytechnic school - traders, technicians, economists, etc.—should not become competitors, but should carry out common work for the sake of the Fatherland (Hollander, 1870). In 1869, the school moves to the new building on the Thronfolger Boulevard (now Rainis boulevard), that had been designed and built by professor Hilbig.

Yet the Department of Commerce was only established in 1868 at the Polytechnic School in Riga, which was the merit of the economist and later professor of the University of Giessen, Étienne Laspeyres. As Laspeyres used the experience of the German schools of commerce, in a letter to the Stock Exchange he stressed the necessity of the further development of the department, so that the Department of Commerce would stand equally alongside with other subjects of the technical school, as the Polytechnic School was the right place for new subjects that were not provided in universities, therefore such highly scientific institution should be based on the economic foundation as strong as the natural science foundation that serves the study process of other universities (Festschrift, 1887). The Department of Commerce began its work with three 
students in the school year 1868/1869. The first student Adolph Kaempffe became his diploma in 1870/1871 (Zehnter, 1871).

In 1896 the Polytechnic School in Riga changed its statutes and its name to the Riga Polytechnic Institute. What had started as a private undertaking became an undertaking of the Russian State with a part of state funding coming along with it. The language of tuition had to be Russian which led to the exodus of all the staff which came from German speaking countries and were not able or not willing to lecture in Russian. This did not concern the generation of scientists which came from the Baltic region as most of them spoke the language of the state they belonged to. The language of tuition changed a third time when Latvia became independent and the language of tuition became Latvian which led to another exodus.

With the Latvian state gaining independence in 1918, the general view was formed that the Department of Trade in its original form no longer met the requirements of the time, yet the opinion on its transformation differed; while carrying out the reforms it became necessary to take into account the actual needs of the country (Schiemann, 1918).

\section{Study Process}

Let's find out how the study process was organized and what subjects were included, what staff worked in the school. The Polytechnic School in Riga was allowed to enroll students not younger than 16 years old. Students to be admitted had to pass a preliminary examination, from which only those could be exempt who had successfully graduated a course at a gymnasium or a similar school. All students of the Polytechnic School were exempted from corporal punishment and recruit obligations.

The statutes of 1861 provided that the subjects of the Polytechnic School were as follows: (1) religious doctrine (for those belonging to Greek Orthodox, Lutheran, and Roman Catholic faith); (2) zoology; (3) botany; (4) mineralogy; (5) experimental physics; (6) general and analytical chemistry; (7) basic and higher mathematics; (8) political economy and industrial statistics; (9) science of products, trade history, and trade geography; (10) trade legislation; (11) trade and shop keeping, accounting and commercial calculations; (12) mechanics and chemistry technology; (13) theoretical and applied mechanics and engineering; (14) civil works and building arts; (15) project drafting and drawing in the fields of mechanics, physics, technology, factory, and agriculture architecture; and (16) Russian, German, French, and English languages - these subjects, in turn, depending on the student's choice that divided into compulsory and optional.

Over time in response to the demand of life as well in line with German technical schools, the original study programmes of the Polytechnic School underwent extensive changes, which also led to the attraction and involvement of a significant number of German teachers to Riga, as well as economists Étienne Laspeyres (1866-1869), Gustav Cohn (1869-1872), August von Miaskowsky (1868-1873), Friedrich Kleinwächter (1872-1875) (Schiemann, 1918).

According to the writings of the professors Franke and Laspeyres, the new school on the one hand took into account the real needs of the regional economy, while on the other hand provided comprehensive and extensive education, which was the basis of the development of all the departments. Namely, during the reorganisation of the Department of Commerce carried out by the Dean, professor Lieventhal, in 1878, not only the scope of subjects was broadened by dividing them into more specific disciplines, but also two new subjects were introduced - Riga commercial institutions and history of national economy; In the further development of the curricula (1900-1914) new subjects were introduced-civil law, statistics, law encyclopaedia 
(Rechtsenzyklopaedie).

The Ministry of People's Enlightenment tried to provide as comprehensive an education as possible; therefore study programmes were overloaded with a large quantity of subjects. The duration of the studies was set to be five years, but in reality it took six to eight years to finish. Many of the Russian students got married during their studies and it was estimated a very negative factor. The lengthy study process had the negative effect that the alumni came quite late into practice, in contrast to Germany, where the young German engineers began to practice as early as after three or four years of education.

After the re-organisation of the school, all the unnecessary ballast was removed from the curricula, and the study programmes were structured into four years according to the German model.

According to the statutes of 1896 the studies in the Department of Trade of the Polytechnic School should last three to five years with the following subjects: (1) theoretical and practical political economy; (2) finance; (3) history of political economy; (4) law; (5) trade geography and statistics; (6) trade history; (7) modern history; (8) trade arithmetic; (9) accounting and office files; (10) chemistry; (11) physics; (12) science of commodities; and (13) languages (Statuti, 1896). In 1896/1897, at the Department of Trade studied 226 students (Sechsunddreissigster, 1897).

The following students were accepted: (1) graduates of institutions of higher education (with certificate of graduation); (2) graduates of the gymnasiums of the Ministry of People's Enlightenment with the certificate of readiness, or the graduates of real-schools with additional class; and (3) graduates of other secondary schools recognised by the Ministry of People's Enlightenment as appropriate for the enrolment into the institute. The Department of Trade accepted also persons with a certification of having worked finished a six year real-school.

At the Department of Trade, those who had successfully passed the final examinations the examination commission awarded them with the Certificate of the Candidate of Trade of the First Class, while the others got a Certificate of the Second Class.

The professors were required to have a doctoral degree, professor's assistants-master's degree. Elected were the persons who had successfully finished a course in a well recognized institution of higher education. Individual subjects (languages, drawing) could be taught after receiving the right to teach at the institutions of higher and secondary education granted by the Ministry of People's Enlightenment (Statuti, 1896). Though at the Polytechnic Institute in Riga the freedom of study was granted, it was demanded that the subjects of the study with practical training (languages, accounting) were acquired in a particular sequence, as it is seen from the aforementioned study plan of the Department of Commerce. Professor von Bergmann believed that it was in the best interest of the students of technical sciences to know economics; therefore the Department of Commerce provided new impulse and force. He also believed that similar to German economic schools the subjects should be taught in-depth, the Department of Commerce should be transformed into the Department of Economics, attracting new staff, offering new study courses in line with the demand of the time, e.g., sourcing of raw materials in Europe (Bergmann, 1918).

The prides of every school are their graduates and their contribution to the national economy. Within its 50 years long existence - from 1868 to 1918 - the Department of Trade has had only about 1,500 students, 1,036 of which have defended the diploma papers (Rīgas Politechnikums, 1938). The graduates have carried on their lives as traders, teachers, and state factory inspectors, tax inspectors, worked in the railway system, managed supermarkets, banks, and factories. As is documented in the "Album Academicum" which gives some 
biographic data about the students of the Polytechnic School and Polytechnic Institute in Riga they did not only come from all over Russia and from other countries of Europe but after having finished they started to work all over the Russian Empire, in western European countries and even in the US.

During the First World War, the growth of the Riga Polytechnic Institute was interrupted. The institute was evacuated to Moscow and worked there till April 1918. When the war was over and Latvia declared its independence only a part of the Institute came back to Riga, but it was closed in August 1919, and in 1919 the University of Latvia was founded which integrated the natural and engineering sciences as new faculties of the university. Only in 1958 the engineering sciences together with the natural sciences got their independence back and the Polytechnic Institute in Riga came to a new life. Keeping alive the traditions of the old Polytechnic School and Polytechnic Institute in 1990, the oldest technical university of the Baltic States got its new name: Riga Technical University. In 1990 the oldest technical university of the Baltic States got its new name: Riga Technical University. The education of economists has once more become the task of this old institution.

\section{Conclusions}

One hundred and fifty years ago the Polytechnic School in Riga (nowadays Riga Technical University) was established. It was the first institution of higher technical education in the Baltic countries. It ensured that Riga within a couple of decades became one of the industrially most developed cities in Europe. It was largely promoted by the acquisition of knowledge about economics. In the further research it is planned to broaden the scope of research both regarding the regional impact and the analysis of the achievements of graduates.

\section{References}

Album Academicum des Polytechnikums zu Riga, 1862-1912 (Album Academicum of the Polytechnic Institute of Riga, 1862-1912). (1912). Riga: Jonck \& Poliewsky.

Bergmann, E. (1918). Die handelswissenschaftliche Abteilung der Baltischen Technischen Hochschule (The trade-scientific department of the Baltic Institute of Technology). Rigaer Akademische Blätter, 2, 20-23.

Bērziņš, A. (1937). Rīgas politechniskā institūta priekšvēsture (Prehistory of Riga Polytechnic Institute). Universitas, 12, 306-307.

Frooben, J. G. (1884). Carl Bornhaupt (pp. 230-232). Riga: b. i.

Hirschhausen, U. V. (2006). Die Grenzen der Gemeinsamkeit (The limits of togetherness). Göttingen: Vandenhoeck \& Ruprecht.

Hollander, E. (1870). Beitrag zur Geschichte des baltischen Polytechnicums (Contribution to the history of the Polytechnic School of the Baltics). Baltische Monatsschrift, 19, 20-37.

Jubilee writing to of the Riga Polytechnic School to celebrate its XXV anniversary (Festschrift der Polytechnischen Schule zu Riga zur Feier ihres XXV jährigen Bestehens). (1887). Riga: b. i.

Kieseritzky, G. (1887). Die Entstehung des baltischen Polytechnikums und die ersten fünfundzwanzig Jahre seines Bestehens (The foundation of the Polytechnic School of the Baltics and the first 25 years of its existence). In Festschrift der Polytechnischen Schule zu Riga zur Feier ihres XXVjährigen Bestehens (pp. 2-45). Riga: Müllersche Buchdruckerei.

Neunter Rechenschaftsbericht des Verwaltungraths der polytechnischen Schule zu Riga (9 Annual Report of the Board of Directors of the Polytechnic School in Riga). (1870). Riga: Livl. Gouvernements-Typographie.

Rīgas Politechnikums: 1862-1919 (The Polytechnic Institute in Riga: 1862-1919). (1938). Rīga: LU Studentu grāmatnīca.

RTU. (2012). The oldest technical university in the Baltics - Ages and personalities, 1862-2012 (p. 109). Riga: RTU.

Schiemann, N. (1918). Die Entwicklung der Maschinen-Ingenieur-Abteilung des Baltischen Polytechnikums zu Riga (The development of the Mechanical Engineering Department of the Baltic Polytechnic in Riga). Rigaer Akademische Blätter, 2 , $17-20$. 
Sechsunddreissigster Rechenschaftsbericht des Verwaltungraths des Rigaschen Polytechnischen Instituts für das Studienjahr 1896/97 (Thirty-sixth Annual Report of the Board of Directors Riga's Polytechnic Institute for the academic year 1896/97). (1897). Riga: Mūller.

Sneps-Sneppe, M. (2011). Nemci v Rossii (Germans in Moscow). Moscow: Algoritm.

Statuti Rīgas politeknikas institutam (Statutes of the Riga Polytechnic Institute). (1896). Baltijas Vēstnesis No.167-169.

Stradinš̌, J. (1982). Etīdes par Latvijas zinātņu pagātni (Sketches about the history of sciences in Latvia) (pp. 25-28). Rīga: Zinātne.

Stradiņš, J. (2009). Zinātnes un augstskola sākotne Latvijā (The beginnings of science and higher education in Latvia) (p. 345). Rīga: Latvijas vēst. inst. apgāds.

Zehnter Rechenschaftsbericht des Verwaltungraths der polytechnischen Schule zu Riga (Tenth Annual Report of the Board of Directors of the Polytechnic School in Riga). (1871). Riga: Livl. Gouvernements-Typographie. 